\title{
"PENGARUH PROFESIONALISME AUDITOR, INDEPENDENSI AUDITOR DAN ETIKA PROFESI TERHADAP KINERJA AUDITOR" (Studi Empiris Pada Kantor Akuntan Publik di Jakarta Barat)
}

\author{
Tagor Darius Sidauruk \\ dan \\ Anisa Sari Fatullah
}

Fakultas Ekonomi Jurusan Akuntansi

Universitas Satya Negara Indonesia

\begin{abstract}
ABSTRAK
Penelitian ini bertujuan untuk memperoleh bukti empiris tentang pengaruh profesionalisme auditor, independensi auditor, dan etika profesi terhadap kinerja auditor.

Populasi dalam penelitian ini adalah auditor yang bekerja di Kantor Akuntan Publik di wilayah Jakarta Barat. Teknik pengambilan sampel yang digunakan dalam penelitian ini adalah menggunakan purposive sampling. Jumlah responden sebanyak 87 dari 9 Kantor Akuntan Publik. Data yang digunakan dalam penelitian ini dikatagorikan sebagai data primer. Teknik pengumpulan data dengan menggunakan instrumen kuesioner. Pengujian data dilakukan dengan menggunakan alat analisis regresi linier berganda.

Hasil penelitian ini menunjukkan bahwa secara parsial variabel profesionalisme auditor, independensi auditor dan etika profesi berpengaruh positif terhadap kinerja auditor. Secara simultan profesionalisme auditor, independensi auditor dan etika profesi mempunyai pengaruh positif terhadap kinerja auditor.
\end{abstract}

Kata Kunci: profesionalisme auditor, independensi auditor, etika profesi, kinerja auditor.

\section{ABSTRAK}

This study aimed to get empirical evidence about the influence of auditor professionalism, auditor independence, and professional ethics on the performance of auditors.

The population of this research was all auditors working on a public accounting firm in West Jakarta. The sampling technique in this research is using purposive sampling. Data techniques collection using questionnaires.

Based on the result of this research, it can be concluded that auditor professionalism positive influence on the performance of auditors, auditor independence positive influence on the performance of auditors, professional ethics positive influence on the performance of auditors, and auditor professionalism, auditor independence and professional ethics influence simultanly had positive effect on the performance auditors.

Keywords: auditor professionalism, auditor independence, professional ethics, auditor performance 


\section{PENDAHULUAN}

\section{Latar Belakang Penelitian}

Pertumbuhan yang kian pesat memaksa perusahaan untuk berlomba-lomba mempertahankan eksistensinya dalam dunia usaha. Dalam rangka menunjang hal tersebut, perusahaan memerlukan jasa auditor untuk melakukan audit atas laporan keuangan. Jasa dari auditor independen digunakan manajemen perusahaan untuk menyakinkan pihak luar (misalnya investor dan kreditor) bahwa laporan keuangan yang disajikan berisi informasi yang dapat dipercaya. Auditor adalah seseorang yang memiliki kualifikasi tertentu dalam melakukan audit atas laporan keuangan dan kegiatan suatu perusahaan atau organisasi. Auditor ditugaskan untuk mengumpulkan dan memeriksa bukti audit untuk memastikan kesesuaian antara informasi dengan kriteria yang ditetapkan dan kemudian mengkomunikasikan kepada user. Peran auditor adalah sebagai mediator antara pemilik dengan manajer pada suatu perusahaan atau pemerintahan.

Sebagai penunjang keberhasilan akuntan publik dalam menjalankan tugas dan fungsinya, sangatlah diperlukan kinerja auditor yang baik dan berkualitas. Kinerja auditor merupakan tindakan atau pelaksanaan tugas pemeriksaan yang telah diselesaikan oleh auditor dalam kurun waktu tertentu.

Sikap profesionalisme perlu ditanamkan dalam diri auditor untuk menunjang pemenuhan tanggung jawab serta menyelesaikan tugas dan fungsinya. Selain profesionalisme, independensi juga mempunyai peran penting bagi auditor guna meningkatkan kinerjanya. Dalam menjalankan tugasnya, auditor harus selalu mempertahankan sikap mental independen di dalam memberikan jasa profesional sebagaimana diatur dalam standar profesional akuntan publik.

Diluar dari kedua faktor tersebut, etika profesi juga merupakan faktor organisasional yang akan mempengaruhi kinerja auditor. Etika profesi adalah sikap etis sebagai bagian integral dari sikap hidup dalam menjalankan kehidupan sebagai pengemban profesi. Setiap auditor harus mematuhi etika profesi mereka agar tidak menyimpang dari aturan dalam menyelesaikan audit laporan keuangan kliennya.

Fenomena-fenomena kasus yang terjadi pada auditor akhir-akhir ini membuat independensi seorang auditor dipertanyakan kembali oleh masyarakat. Salah satu dari beberapa kasus antara lain kasus Telkom di Indonesia tentang KAP Eddy Pianto yang diragukan kelayakan hak berpraktek karena dianggap tidak dapat menyelesaikan dan tidak mampu melakukan pekerjaan audit terhadap Laporan Keuangan PT. Telkom, serta mendapatkan sanksi pembekuan ijin beroperasi di lantai bursa untuk melakukan audit terhadap laporan keuangan perseroan akibat perlakuan tidak sehat dari KAP Hadi Sutanto sebagai KAP first layer yang tidak bersedia terasosiasi dengan pekerjaan audit KAP Eddy Pianto sebagai second layer. Kasus lainnya yaitu kasus pelanggaran yang dilakukan KAP Justinus Aditya Sidharta dalam mengaudit laporan keuangan PT. Great River Internasional, dimana KAP Justinus Aditya Sidharta dianggap telah menyalahi aturan mengenai kode etik profesi akuntan, terutama yang berkaitan dengan integritas dan objektivitas. KAP Justinus Aditya Sidharta dianggap telah melakukan tindak kebohongan publik, dimana tidak melaporkan kondisi keuangan PT Great River International, Tbk secara jujur. 
Dari dua kasus tersebut dapat kita simpulkan, bahwa seorang akuntan publik sudah seharusnya mentaati dan memegang secara teguh Standar Profesional Akuntan Publik (SPAP).

Dalam penelitian Ernawati Putri Solikhah (2017), menyimpulkan bahwa profesionalisme auditor berpengaruh positif terhadap kinerja auditor. Berbeda dengan hasil penelitian I Gede Bandar Wira Putra dan Dodik Ariyanto (2012), bahwa profesionalisme tidak terbukti berpengaruh terhadap kinerja auditor. Pada penelitian Listiya Nuraini (2016), menyebutkan bahwa independensi auditor berpengaruh positif terhadap kinerja auditor, sedangkan pada penelitian Ismail Pamilih (2011) bahwa independensi tidak berpengaruh signifikan terhadap kinerja auditor. Anis Choiriah (2013) menyimpulkan bahwa etika profesi berpengaruh positif terhadap kinerja auditor. Sedangkan penelitian Riris Rotua Sitorus dan Lenny Wijaya (2016) bahwa etika profesi tidak berpengaruh signifikan terhadap kinerja auditor.

Berdasarkan latar belakang di atas, maka peneliti akan melakukan penelitian dengan judul "Pengaruh Profesionalisme Auditor, Independensi Auditor, dan Etika Profesi Terhadap Kinerja Auditor" (Studi Empiris Pada Kantor Akuntan Publik di Jakarta Barat).

\section{Perumusan Masalah}

Berdasarkan latar belakang di atas, maka perumusan masalah dalam penelitian ini adalah sebagai berikut:

1. Apakah profesionalisme auditor berpengaruh terhadap kinerja auditor?

2. Apakah independensi auditor berpengaruh terhadap kinerja auditor?

3. Apakah etika profesi berpengaruh terhadap kinerja auditor?

4. Apakah profesionalisme auditor, independensi auditor dan etika profesi berpengaruh terhadap kinerja auditor?

\section{Tujuan Penelitian}

Berdasarkan perumusan masalah diatas, maka tujuan dari penelitian ini adalah sebagai berikut:

1. Untuk mengetahui pengaruh profesionalisme auditor terhadap kinerja auditor.

2. Untuk mengetahui Pengaruh independensi auditor terhadap kinerja auditor.

3. Untuk mengetahui Pengaruh etika profesi terhadap kinerja auditor.

4. Untuk mengetahui Pengaruh profesionalisme auditor, independensi auditor, dan etika profesi terhadap kinerja auditor.

\section{LANDASAN TEORI}

\section{Profesionalisme Auditor}

Adapun persyaratan profesionalisme auditor menurut Standar Profesi Akuntan Publik (201) bahwa:

a. Auditor independen adalah orang yang memiliki pendidikan dan pengalaman berpraktik sebagai auditor independen. 
b. Auditor independen harus menggunakan pertimbangannya dalam menentukan prosedur audit yang diperlukan sesuai dengan keadaan, sebagai basis memadai bagi pendapatnya, pertimbangannya harus merupakan pertimbangan berbasis informasi dari seorang profesional yang ahli.

c. Auditor independen juga bertanggung jawab terhadap profesinya, tanggung jawab untuk mematuhi standar yang diterima oleh para praktisi rekan seprofesinya.

Berdasarkan uraian diatas maka dapat disimpulkan, Profesionalisme adalah perilaku bertanggung jawab atas suatu profesi sesuai dengan ketentuan, peraturan, dan undang-undang dimana hal tersebut sebagai bentuk tanggung jawabnya terhadap masyarakat, klien dan pemakai laporan keuangan lain.

\section{Independensi Auditor}

Menurut SPAP (2011) independensi adalah tidak mudah dipengaruhi, karena ia melaksanakan pekerjaannya untuk kepentingan umum. Dengan demikian, ia tidak dibenarkan memihak kepada kepentingan siapapun, sebab bagaimanapun sempurnanya keahlian teknis yang ia miliki, ia akan kehilangan sikap tidak memihak yang justru paling penting untuk mempertahankan kebebasan pendapatnya.

Menurut Kode Perilaku Profesional American Institute od Certified Public Accountants (AICPA) dan Kode Etik bagi Perilaku Profesional International Ethics Standards Board of Accountants (IESBA) mendefinisikan independensi sebagai (Arens et al, 2014): hal yang terdiri dari dua komponen: independensi dalam berpikir dan independensi dalam penampilan. Independensi dalam berpikir (independence in mind) mencerminkan pikiran auditor yang memungkinkan audit dilaksanakan dengan sikap yang tidak bias. Independensi dalam berpikir mencerminkan persyaratan lama bahwa anggota harus independen dalam fakta. Independensi dalam penampilan (independence in appearance) adalah hasil dari interprestasi lain atas independensi ini.

Independensi menurut Mulyadi (2013: 26) dapat diartikan sebagai sikap mental yang bebas dari pengaruh, tidak dikendalikan oleh pihak lain, tidak tergantung pada orang lain. Independensi juga berarti adanya kejujuran dalam diri auditor mempertimbangkan fakta dan adanya pertimbangan yang objektif tidak memihak dalam diri auditor dalam merumuskan dan menyatakan pendapatnya.

Dari definisi yang telah diuraikan, dapat disimpulkan independensi adalah sikap tidak memihak dan tidak dapat dipengaruhi oleh kepentingan siapapun, dimana dalam hal ini seorang auditor harus menanamkan sikap kejujuran dalam dirinya.

Keadaan yang seringkali mengganggu sikap mental independen auditor adalah sebagai berikut:

a. Sebagai seorang yang melaksanakan audit secara independen, auditor dibayar oleh kliennya atas jasanya tersebut.

b. Sebagai penjual jasa seringkali auditor mempunyai kecenderungan untuk memuaskan keinginan kliennya.

c. Mempertahankan sikap mental independen seringkali dapat menyebabkan lepasnya klien. 
Standar umum audit yang kedua menyatakan bahwa dalam semua hal yang berhubungan dengan perikatan, independensi dalam sikap mental harus dipertahankan oleh auditor. Berkaitan dengan hal itu terdapat empat hal yang mengganggu independensi akuntan publik, antara lain:

a. Akuntan publik memiliki mutual atau conflicting interest dengan klien,

b. Mengaudit pekerjaan akuntan publik itu sendiri,

c. Berfungsi sebagai manajemen atau karyawan dari klien dan

d. Bertindak sebagai penasihat (advocate) dari klien.

\section{Etika Profesi}

Menurut Arens et al (2014), Etika (ethics) secara garis besar didefinisikan sebagai serangkaian prinsip atau nilai moral. Menurut Islahuzzaman (2012) Etika Profesional adalah: sekumpulan prinsip atau nilai moral yang dikeluarkan oleh organisasi untuk mengetahui perilaku anggotanya dalam menjalankan praktik profesinya bagi masyarakat. Etika Profesi merupakan kode etik untuk profesi tertentu dan karenanya harus dimengerti selayaknya, bukan sebagai etika absolut. Etika profesi disebut juga sikap etis sebagai bagian integral dari sikap hidup dalam menjalankan kehidupan sebagai pengemban profesi.

Setiap praktisi wajib mematuhi prinsip dasar etika profesi di bawah ini, antara lain: (SPAP, 2011):

a. Prinsip Integritas

Setiap praktisi harus tegas dan jujur dalam menjalin hubungan profesional dan hubungan bisnis dalam melaksanakan pekerjaannnya.

b. Prinsip Objektivitas

Setiap praktisi tidak boleh membiarkan subjektivitas, benturan kepentingan, atas pengaruh yang tidak layak (undue influence) dari pihak-pihak lain memengaruhi pertimbangan profesional atau pertimbangan bisnisnya.

c. Prinsip Kompetensi serta sikap kecermatan dan kehati-hatian profesional (professional competence and due care)

Setiap praktisi wajib memelihara pengetahuan dan keahlian profesionalnya pada suatu tingkatan yang dipersyaratkan secara berkesinambungan, sehingga klien atau pemberi kerja dapat menerima jasa profesional yang diberikan secara kompeten berdasarkan perkembangan terkini dalam praktik, perundang-undangan, dan metode pelaksanaan pekerjaan. Setiap praktisi harus bertindak secara profesional dan sesuai dengan standar profesi dan kode etik profesi yang berlaku dalam memberikan jasa profesionalnya.

d. Prinsip Kerahasiaan

Setiap praktisi wajib menjaga kerahasiaan informasi yang diperoleh sebagai hasil dari hubungan profesional dan hubungan bisnisnya, serta tidak boleh mngungkapkan informasi tersebut kepada pihak ketiga tanpa persetujuan dari klien atau pemberi kerja, kecuali jika terdapat kewajiban untuk mengungkapkan sesuai dengan ketentuan hukum atau peraturan lainnya yang berlaku. Informasi rahasia yang diperoleh dari hubungan profesional dan hubungan bisnis tidak boleh digunakan oleh praktisi untuk keuntungan pribadinya atau pihak ketiga.

e. Prinsip Perilaku Profesional

Setiap praktisi wajib mematuhi hukum dan peraturan yang berlaku dan harus menghindari semua tindakan yang dapat mendiskreditkan profesi. 


\section{Kinerja Auditor}

Kinerja pada dasarnya merupakan hasil kerja seseorang yang menggambarkan kualitas dan kuantitas atas kerja yang telah dicapai oleh seseorang dalam melaksanakan tugasnya sesuai dengan tanggung jawabnya.

Menurut Mulyadi (2013: 11) kinerja auditor adalah: auditor melaksanakan penugasan pemeriksaan (examination) secara objektif atas laporan keuangan suatu perusahaan atau organisasi lain dengan tujuan untuk menentukan apakah laporan keuangan tersebut menyajikan secara wajar sesuai dengan prinsip akuntansi yang berlaku umum, dalam semua hal yang material, posisi keuangan dan hasil usaha perusahaan. Kinerja auditor adalah tindakan atau pelaksanaan tugas pemeriksaan yang telah diselesaikan oleh auditor dalam kurun waktu tertentu.

Sebagai bentuk pengawasan atas kinerja auditor, kantor akuntan publik (KAP) memerlukan pengendalian mutu (quality control). Menurut Arens et al (2014) pengendalian mutu adalah: Metode-metode yang digunakan oleh sebuah kantor akuntan publik untuk memastikan bahwa kantor tersebut telah memenuhi tanggung jawab profesionalnya kepada klien maupun pihak lainnya.

Pengukuran kinerja yang dominan dalam mempertimbangkan penilaian kinerja, sebagai berikut:

a. Kuantitas. Kuantitas adalah jumlah yang harus diselesaikan atau dicapai. Pengukuran kuantitatif melibatkan perhitungan keluaran dari proses atau pelaksanaan kegiatan. Ini berkaitan dengan jumlah keluaran atau pelaksanaan kegiatan.

b. Kualitas. Kualitas adalah mutu yang harus dihasilkan (baik tidaknya), pengukuran kualitatif mencerminkan pengukuran "tingkat kepuasan", yaitu seberapa baik penyelasainnya.

c. Ketepatan waktu. Ketepatan waktu, yaitu sesuai tidaknya dengan waktu yang direncanakan. Pengukuran ketepatan waktu merupakan jenis khusus dari pengukuran kuantitatif yang menentukan ketepatan waktu penyelesaian suatu kegiatan.

\section{Standar dan Prosedur Audit}

Dalam menjalankan tugas dan fungsinya, seorang auditor harus dapat memenuhi kaidah-kaidah dalam standar auditing. Standar auditing merupakan pedoman umum bagi auditor dalam memenuhi tanggung jawab profesionalnya.

Standar auditing yang menjadi pedoman para auditor adalah standar yang telah ditetapkan dan disahkan oleh Institut Akuntan Publik Indonesia (SPAP, 2011) yang terdiri atas sepuluh standar yang dikelompokkan menjadi tiga kelompok besar, antara lain:

a. Standar Umum. (1) Audit harus dilaksanakan oleh seorang atau lebih yang memiliki keahlian dan pelatihan teknis yang cukup sebagai auditor. (2) Dalam semua hal yang berhubungan dengan perikatan, independensi dalam sikap mental harus dipertahankan oleh auditor. (3) Dalam pelaksanaan audit dan penyusunan laporannya, auditor wajib menggunakan kemahiran profesionalnya dengan cermat dan seksama. 
b. Standar Pekerjaan Lapangan. (1) Pekerjaan harus direncanakan sebaik-baiknya dan jika digunakan asisten harus disupervisi dengan semestinya. (2) Pemahaman memadai atas pengendalian intern harus diperoleh untuk merencanakan audit dan menentukan sifat, saat, dan lingkup pengujian yang akan dilakukan. (3) Bukti audit kompeten yang cukup harus diperoleh melalui inspeksi, pengamatan, permintaan keterangan, dan konfirmasi sebagai dasar memadai untuk menyatakan pendapat atas laporan keuangan yang diaudit.

c. Standar Pelaporan. (1) Laporan auditor harus menyatakan apakah laporan keuangan telah disusun sesuai dengan standar akuntansi yang berlaku umum di Indonesia. (2) Laporan auditor harus menunjukkan atau menyatakan, jika ada ketidakkonsistenan penerapan standar akuntansi dalam penyusunan laporan keuangan periode berjalan dibandingkan dengan penerapan standar akuntansi tersebut dalam periode sebelumnya. (3) Pengungkapan informatif dalam laporan keuangan harus dipandang memadai, kecuali dinyatakan lain dalam laporan auditor. (4) Laporan auditor harus memuat suatu pernyataan pendapat mengenai laporan keuangan secara keseluruhan atau suatu asersi bahwa pernyataan demikian tidak dapat diberikan. Jika pendapat secara keseluruhan tidak dapat diberikan, maka alasannya harus dinyatakan. Dalam hal nama auditor dikaitkan dengan laporan keuangan, maka laporan auditor harus memuat petunjuk yang jelas mengenai sifat pekerjaan audit yang dilaksanakan, jika ada, dan tingkat tanggung jawab yang dipikul oleh auditor.

Bukti audit diperoleh auditor melalui penerapan prosedur audit. Pemilihan prosedur dilakukan saat tahap perencanaan audit. Pemilihan prosedur audit mempertimbangkan efektivitas potensial prosedur dalam memenuhi tujuan spesifik audit, dan biaya untuk melakukan prosedur tersebut. Prosedur berkaitan dengan tindakan yang harus dilaksanakan (SPAP, 2011:150.1). Prosedur audit berkaitan dengan tidak hanya kualitas profesional auditor namun juga berkaitan dengan pertimbangan yang digunakan dalam pelaksanaan auditnya dan dalam laporannya.

Berikut prosedur audit yang biasa dilakukan auditor, antara lain:

a. Inspeksi. Inspeksi merupakan pemeriksaan secara rinci terhadap dokumen atau kondisi fisik sesuatu. Prosedur audit ini banyak dilakukan oleh auditor. Dengan melakukan inspeksi terhadap sebuah dokumen, auditor akan dapat menentukan keaslian dokumen tersebut. Dengan melakukan inspeksi terhadap kondisi fisik suatu aktiva tetap misalnya, auditor akan dapat memperoleh informasi mengenai eksistensi dan keadaan fisik aktiva tersebut.

b. Pengamatan (observation). Pengamatan merupakan prosedur audit yang digunakan oleh auditor untuk melihat atau menyaksikan pelaksanaan suatu kegiatan. Dengan pengamatan ini auditor akan dapat memperoleh bukti visual mengenai pelaksanaan suatu kegiatan. Objek yang diamati auditor adalah karyawan, prosedur, dan proses.

c. Permintaan Keterangan (enquiry). Permintaan keterangan merupakan prosedur audit yang dilakukan dengan meminta keterangan secara lisan. Bukti audit yang dihasilkan dari prosedur ini adalah bukti lisan dan bukti dokumenter.

d. Konfirmasi. Konfirmasi merupakan bentuk penyelidikan yang memungkinkan auditor memperoleh informasi secara langsung dari pihak ketiga yang bebas. Prosedur yang biasa ditempuh oleh auditor dalam konfirmasi ini adalah sebagai berikut: (1) Auditor meminta dari klien untuk menanyakan informasi tertentu kepada pihak luar. (2) Klien meminta kepada pihak luar yang ditunjuk oleh auditor untuk memberikan jawaban langsung kepada 
auditor mengenai informasi yang ditanyakan oleh auditor tersebut. (3) Auditor menerima jawaban langsung dari pihak ketiga tersebut.

e. Penelusuran (tracing). Dalam melaksanakan prosedur audit ini, auditor melakukan penelusuran informasi sejak mula-mula data tersebut direkam pertama kali dalam dokumen, dilanjutkan dengan pelacakan pengolahan data tersebut dalam proses akuntansi. Prosedur audit ini terutama diterapkann terhadap bukti dokumenter.

f. Pemeriksaan bukti pendukung (vouching). Pemeriksaan bukti pendukung merupakan prosedur audit yang meliputi: (1) Inspeksi terhadap dokumen-dokumen yang mendukung suatu transaksi atau data keuangan untuk menentukan kewajaran dan kebenarannya. (2) Pembandingan dokumen tersebut dengan catatan akuntansi yang berkaitan. Prosedur ini berlawanan arahnya dengan prosedur penelusuran. Dalam penelusuran, auditor bertolak dari dokumen kemudian mengusut pencatatannya ke dalam catatan-catatan akuntansi yang berkaitan, sedangkan dengan vouching, auditor bertolak dari catatan akuntansi, kembali memeriksa dokumen-dokumen yang mendukung informasi yang dicatat dalam catatan tersebut.

g. Penghitungan (counting).

Prosedur audit ini meliputi: (1) penghitungan fisik terhadap sumber daya berwujud seperti kas atau sediaan di tangan, dan (2) pertanggungjawaban semua formulir bernomor urut tercetak. Penghitugan fisik digunakan untuk mengevaluasi bukti fisik kuantitas yang ada di tangan, sedangkan pertanggungjawaban formulir bernomor urut tercetak digunakan untuk mengevaluasi bukti dokumenter yang mendukung kelengkapan catatan akuntansi.

h. Scanning. Scanning merupakan review secara cepat terhadap dokumen, catatan dan daftar untuk mendeteksi unsur-unsur yang tampak tidak biasa yang memerlukan penyelidikan lebih mendalam.

i. Pelaksanaan ulang (reperfoming). Prosedur audit ini merupakan pengulangan aktivitas yang dilaksanakan oleh klien. Umumnya pelaksanaan ulang diterapkan pada penghitungan dan rekonsiliasi yang telah dilakukan oleh klien.

\section{METODOLOGI PENELITIAN}

\section{Waktu dan Tempat Penelitian}

Penelitian ini dilakukan selama 4 bulan yaitu dimulai bulan Maret 2018 sampai dengan Juni 2018, pada Kantor Akuntan Publik di wilayah Jakarta Barat, yang bersedia menerima peneliti.

\section{Desain Penelitian}

Desain penelitian yang digunakan adalah penelitian kausal (causal research) yang merupakan penelitian untuk mengetahui pengaruh antara satu atau lebih variabel bebas terhadap variabel terikat.

\section{Variabel Penelitian}

Variabel yang digunakan dalam penelitian ini adalah sebagai berikut:

a. Variabel bebas atau independen: variabel bebas yang digunakan dalam penelitian ini adalah profesionalisme auditor $\left(\mathrm{X}_{1}\right)$, independensi auditor $\left(\mathrm{X}_{2}\right)$, dan etika profesi $\left(\mathrm{X}_{3}\right)$.

b. Variabel terikat atau dependen: variabel terikat yang digunakan dalam penelitian ini adalah kinerja auditor. 


\section{Jenis dan Sumber Data}

Dalam penelitian ini peneliti menggunakan data primer. Data primer adalah diperoleh langsung dari responden yaitu dengan kuesioner sebagai instrumen untuk pengumpulan data.

\section{Populasi dan Sampel}

Populasi yang digunakan dalam penelitian ini adalah auditor yang bekerja di Kantor Akuntan Publik di wilayah Jakarta Barat yang terdaftar pada Directory Kantor Akuntan Publik yang dikeluarkan IAPI.

Teknik penarikan sampel yang digunakan dalam penelitian ini adalah teknik purposive sampling yaitu teknik pengambilan sampel yang didasarkan atas pertimbanganpertimbangan tertentu dari peneliti dengan kriteria sebagai berikut: (a) Auditor yang memiliki pengalaman minimal 2 tahun, hal ini dilakukan karena auditor tersebut telah memahami pekerjaan audit. (b) Jenjang pendidikan minimal S1.

\section{Metode dan Teknik Pengumpulan Data}

Metode pengumpulan data yang digunakan dalam penelitian ini adalah: (1) metode penelitian kepustakaan (library research): penelitian dengan mengumpulkan data dengan cara membaca dan mempelajari buku-buku yang ada dan sumber data yang lainnya berkaitan dengan pembahasan masalah yang dibutuhkan, dan (2) metode penelitian lapangan (field research): metode dengan mengunjungi objek penelitian guna memperoleh data-data yang diperlukan dalam penelitian tersebut.

Teknik pengumpulan data dilakukan menggunakan instrumen berupa kuesioner yang akan disebarkan ke beberapa KAP yang ada di wilayah Jakarta Barat. Kuesioner yang berisi daftar pertanyaan kepada responden yang akan disebarkan untuk semua auditor yang bekerja di Kantor Akuntan Publik yang dilakukan penelitian.

\section{Metode Analisis Data Statistik Deskriptif}

Statistik deskriptif yaitu suatu teknik analisis data yang berusaha menjelaskan atau menggambarkan berbagai karakteristik data. Analisis ini menjelaskan atau menarik kesimpulan dari variabel yang diteliti meliputi : nilai minimum, nilai maksimum, nilai ratarata (mean) dan standar deviasi dari masing-masing variabel.

\section{Uji Instrumen Penelitian Uji Validitas}

Uji validitas digunakan untuk mengukur sah atau valid tidaknya suatu kuesioner. Valid yang dimaksud terlihat dari pertanyaan pada kuesioner, pertanyaan tersebut harus dapat menggambarkan sesuatu yang akan diukur oleh kuesioner tersebut. Jenis pengujian yang dilakukan dalam penelitian ini adalah dengan melakukan korelasi antar skor butir pertanyaan dengan total skor konstruk atau variabel. Dalam pengujian ini diajukan hipotesis: 
Ho : Skor butir pertanyaan berkorelasi positif dengan total skor konstruk.

$\mathrm{Ha}$ : Skor butir pertanyaan tidak berkorelasi positif dengan total skor konstruk.

Uji signifikan ini dilakukan dengan membandingkan nilai $r$ hitung dengan $r$ tabel untuk degree of freedom $(\mathrm{df})=\mathrm{n}-2$, dalam hal ini $\mathrm{n}$ adalah jumlah sampel. Validitas suatu butir pertanyaan dapat dilihat pada hasil output SPSS pada tabel Correlated Item - Total Correlation. Caranya dengan melihat $\mathrm{r}$ hitung dibandingkan dengan $\mathrm{r}$ tabel pada tabel Product Moment. Jika $\mathrm{r}$ hitung lebih besar dari $\mathrm{r}$ tabel dan nilai positif maka butir atau pertanyaan atau indikator tersebut dinyatakan valid.

\section{Uji Realibilitas}

Reliabilitas sebenarnya adalah alat ukur untuk mengukur suatu kuesioner yang merupakan indikator dari variabel atau konstruk. Suatu kuesioner dikatakan reliable atau handal jika jawaban seseorang terhadap pernyataan adalah konsisten atau stabil dari waktu ke waktu. SPSS memberikan fasilitas untuk mengukur realibilitas dengan uji statistik Crobanch Alpha $(\alpha)$ suatu konstruk atau variabel dikatakan reliable jika memberikan nilai Crobanch Alpha $>0.70$ (Nunnally, 1994).

\section{Uji Asumsi Klasik Uji Normalitas}

Model regresi yang baik adalah memiliki distribusi data normal atau mendekati normal. Normalitas dapat dideteksi dengan menggunakan uji statistik, yaitu KolmogorovSmirnov Test (Imam Ghozali, 2005: 30). Adapun kriteria pengujian adalah: (1) apabila nilai signifikan Kolmogorov-Smirnov Test adalah $<0.05$ maka data residual tidak berdistribusi normal, dan sebaliknya (2) apabila nilai signifikan Kolmogorov-Smirnov Test adalah $>0.05$ maka data residual berdistribusi normal.

\section{Uji Autokorelasi}

Model regresi yang baik seharusnya tidak menunjukkan autokorelasi. Untuk mendeteksi ada tidaknya autokorelasi, maka nilai DW (Durbin Watson) akan dibandingkan dengan tabel DW. Kriteria yang dipakai adalah sebagai berikut: (1) Jika d lebih kecil dari dL atau lebih besar dari (4-dL) maka hipotesis nol ditolak, yang berarti terdapat autokorelasi. (2) Jika d terletak antara dU dan (4-dU), maka hipotesis nol diterima, yang berarti tidak ada autokorelasi. (3) Jika d terletak antara dL dan dU atau dimana (4-dU) dan (4-dL), maka tidak menghasilkan kesimpulan yang pasti.

\section{Uji Multikolinieritas}

Model regresi yang baik seharusnya tidak terjadi korelasi diantara variabel independen (Imam Ghozali, 2005: 91). Untuk mendeteksi ada tidaknya multikolinearitas dalam suatu persamaan regresi adalah sebagai berikut: nilai Tolerance yang rendah maka akan berakibat pada VIF yang tinggi, dan ini berarti terjadi multikolinearitas. Dan sebaliknya, persamaan regresi tidak terjadi multikolinieritas jika nilai Tolerance $>0.10$, dan besarnya VIF $<10$. 


\section{Uji Heteroskedastisitas}

Model regresi yang baik adalah tidak terjadi heteroskedastisitas. Dalam mendeteksi ada atau tidaknya Heterokedastisitas peneliti menggunakan uji dengan melihat Grafik Plot antara nilai prediksi variabel terikat (dependen) dengan residualnya. Dasar analisis adalah (Imam Ghozali, 2005: 105): (a) jika ada pola tertentu, seperti titik-titik yang ada membentuj suatu pola tertentu yang teratur, maka telah terjadi heteroskedastisitas. (b) jika tidak ada pola yang jelas, serta titik-titik menyebar di atas dan di bawah angka nol pada sumbu Y, maka tidak terjadi heteroskedastisitas.

\section{Analisis Regresi Linier Berganda}

Analisis regresi linier berganda berguna untuk menganalisa hubungan linier antara 2 variabel independen atau lebih dengan 1 variabel dependen. Dalam uji regresi peneliti menggunakan regresi linier berganda untuk mencari pengaruh antar variabel dengan model sebagai berikut:

Keterangan:

$$
\mathrm{Y}=\mathrm{a}+\beta_{1} \mathrm{X}_{1}+\beta_{2} \mathrm{X}_{2}+\beta_{3} \mathrm{X}_{3}+\mathrm{e}
$$

$$
\begin{array}{ll}
\mathrm{Y} & =\text { Kinerja auditor } \\
\mathrm{X}_{1} & =\text { Profesionalisme Auditor } \\
\mathrm{X}_{2} & =\text { Independensi Auditor } \\
\mathrm{X}_{3} & =\text { Etika profesi } \\
\beta_{1} \beta_{2} \beta_{3} & =\text { Koefisien regresi } \\
\mathrm{a} & =\text { Konstanta } \\
\mathrm{e} & =\text { Error term }
\end{array}
$$

\section{Uji Hipotesis}

\section{Koefisien Determinasi (Uji $\mathbf{R}^{2}$ )}

Untuk menyatakan besar kecilnya sumbangan variabel X terhadap Y dapat ditentukan dengan koefisien determinasi. Pada koefisien determinasi $\left(\mathrm{R}^{2}\right)$ pada intinya mengukur seberapa jauh kemampuan model dalam menerangkan variasi variabel dependen. Nilai $\mathrm{r}^{2}$ adalah antara 0 dan $1\left(0<\mathrm{R}^{2}<1\right)$, dimana suatu regresi yang baik akan menghasilkan nilai $\mathrm{r}^{2}$ yang tinggi. Hal ini berarti bahwa keseluruhan variabel bebas secara bersama-sama mampu menerangkan variabel terikatnya. Sedangkan $r^{2}$ yang kecil berarti kemampuan variabelvariabel dependen sangat terbatas (Ghozali, 2016).

\section{Uji statistik t (Uji Signifikan Parsial)}

Uji hipotesis dalam penelitian ini diuji menggunakan model regresi linier berganda. Uji statistik t pada dasarnya menunjukkan seberapa jauh pengaruh satu variabel independen secara individual dalam menerangkan variasi varibel dependen. Hipotesis nol (H0) yang hendak diuji adalah apakah suatu parameter sama dengan nol, atau $\mathrm{H}$ ) : bi $=0$. Hipotesis alternatifnya (HA) parameter suatu variabel tidak sama dengan nol, atau HA : ba $\neq 0$. Uji parsial ditunjukkan oleh tabel Coeficients dalam hasil output SPSS. Selanjutnya untuk mengetahui signifikan pengaruh atau hubungan antar variabel dapat dilakukan pengambilan keputusan dengan kriteria sebagai berikut: (1) jika probabilitas $>0.05$, maka H0 tidak dapat 
ditolak, jadi variance sama. (2) jika probabilitas $<0.05$, maka H0 ditolak, jadi variance berbeda.

\section{Uji statistik F (Uji Signifikan Simultan)}

Uji simultan ditunjukkan oleh tabel Anova. Uji statistik F menunjukkan apakah semua variabel independen yang dimasukkan dalam model mempunyai pengaruh secara bersamasama terhadap variabel terikat. Hipotesis nol (H0) yang hendak diuji adalah apakah semua parameter dalam model sama dengan nol, atau $\mathrm{H} 0: \mathrm{b} 1=\mathrm{b} 2=\ldots=\mathrm{bk}=0$. Hipotesis alternatifnya adalah tidak semua parameter secara simultan sama dengan nol, atau HA : b1 $\neq$ $\mathrm{b} 2 \neq \ldots \ldots \mathrm{bk} \neq 0$. Menentukan tingkat signifikan $(\alpha)$ yaitu sebesar $5 \%$ dapat dilakukan dengan berdasarkan nilai probabilitas, dengan cara: (1) Jika probabilitas $>0.05$ maka H0 tidak dapat ditolak, jadi variance sama. (2) Jika probabiliitas $<0.05$ maka H0 ditolak, variabel independen secara simultan mempengaruhi variabel terikat.

\section{ANALISIS HASIL DAN PEMBAHASAN}

\section{Statistik Deskriptif}

Identifikasi responden memberikan gambaran mengenai karakteristik responden yang ditunjukkan dengan besarnya frekuensi dan persentase dari Usia, Jenis Kelamin, Jenjang Pendidikan dan Lama Bekerja. Pengolahan data ini menggunakan program Statistical Package for the Social Science (SPSS).

1. Karakteristik berdasarkan usia. Usia responden $20-25$ tahun sebanyak 7 orang $(8 \%)$, rentang usia 26-30 tahun sebanyak 41 orang $(47,1 \%)$, rentang usia 31-35 tahun sebanyak 36 orang $(41,4 \%)$, untuk rentang usia $36-40$ tahun sebanyak 3 orang $(3,4 \%)$ dan tidak ada responden dengan usia $>40$ tahun.

2. Karakteristik berdasarkan jenis kelamin. Ada 40 orang (46\%) berjenis kelamin laki-laki dan 47 orang (54\%) adalah perempuan.

3. Karakteristik berdasarkan jenjang pendidikan. Terdapat 85 orang $(97,7 \%)$ yang berpendidikan $\mathrm{S} 1$, terdapat 2 orang $(2,3 \%)$ yang berpendidikan $\mathrm{S} 2$, dan tidak ada responden yang memiliki jenjang pendidikan D3/D4 dan S3.

4. Karakteristik responden berdasarkan lamanya bekerja. Lama bekerja responden 2-5 tahun sebanyak 39 orang $(44,8 \%)$, lama bekerja 6-10 tahun sebanyak 46 orang $(52,9 \%)$, dan untuk lama bekerja $>10$ tahun sebanyak 2 orang $(2,3 \%)$ dan tidak ada responden yang bekerja bekerja $<2$ tahun.

\section{Uji Instumen Penelitian \\ Uji validitas}

Uji validitas digunakan untuk mengukur valid tidaknya suatu kuesioner. Validitas suatu butir pertanyaan dapat dilihat pada hasil output SPSS pada kolom Correlated Item Total Correlation (nilai $\mathrm{r}$ hitung). Uji validitas ini dilakukan dengan membandingkan nilai $\mathrm{r}$ hitung dengan $r$ tabel. Nilai $r$ tabel diperoleh dengan rumus degree of freedom $(\mathrm{df})=\mathrm{n}-2$, dalam hal ini $\mathrm{n}$ adalah jumlah responden. Dalam penelitian ini $\mathrm{df}=87-2$ atau $\mathrm{df}=85$ dengan $\alpha 0,05$ didapat $r$ tabel sebesar 0,211. Jika koefisien korelasi (r) bernilai positif dan lebih besar dari $r$ tabel, maka dinyatakan bahwa butir pernyataan tersebut valid atau sah. 
Berdasarkan hasil pengujian yang dilakukan bahwa untuk variabel profesional auditor adalah valid, dimana setiap butir pernyataan nilai $r$ hitung $>$ dari $r$ tabel. Begitu juga dengan variabel independensi auditor, etika profesi, dan kinerja auditor, semua menunjukkan valid.

\section{Uji realibilitas}

Software SPSS memberikan fasilitas untuk mengukur Realibilitas dengan uji statistik Crobanch Alpha $(\alpha)$ suatu konstruk atau variabel dikatakan reliable jika memberikan nilai Crobanch Alpha $>0.70$ (Nunnally, 1994).

a. Uji Reliabilitas Profesionalisme Auditor (X1) menunjukkan bahwa Cronbach's Alpha $0,711>0,70$. Dapat disimpulkan bahwa pernyataan-pernyataan dalam variabel profesionalisme auditor adalah reliable, artinya bahwa hasil pengukuran variabel profesionalisme auditor adalah konsisten.

b. Uji Reliabilitas independensi auditor, menunjukkan bahwa Cronbach's Alpha 0,734 > 0,70. Dapat disimpulkan bahwa pernyataan-pernyataan dalam variabel independensi auditor adalah reliable.

c. Uji Reliabilitas etika profesi, Cronbach's Alpha 0,737>0,70. Dapat disimpulkan bahwa pernyataan-pernyataan dalam variabel etika profesi adalah reliable.

d. Uji Reliabilitas kinerja auditor, Cronbach's Alpha 0,770 >0,70. Dapat disimpulkan bahwa pernyataan-pernyataan dalam variabel kinerja auditor adalah reliable.

\section{Uji Asumsi Klasik}

Uji asumsi klasik dalam penelitian ini meliputi:

\section{Uji Normalitas}

Normalitas dapat diketahui dengan melihat tabel One-Sample Kolmogorov-Smirnov Test pada kolom Asymp.Sig (2-tailed) yaitu jika p value (sig) $>0.05$ maka dapat disimpulkan bahwa data yang diambil dari populasi berdistribusi normal. Berdasarkan hasil output SPSS, diperoleh hasil Asymp.Sig. (2-tailed) untuk variabel profesionalisme auditor (X1), independensi auditor (X2), etika profesi (X3), dan kinerja auditor (Y) adalah sebesar 0,77 . Maka untuk keempat variabel tersebut adalah 0,77>0.05. Karena Asymp. Sig $>$ dari 0.05, maka dapat disimpulkan bahwa data yang diambil dari populasi berdistribusi normal.

\section{Uji Autokorelasi}

Model regresi yang baik seharusnya tidak adalah regresi yang bebas dari autokorelasi. Metode pengujian yang sering digunakan untuk mengetahui autokorelasi adalah dengan uji Durbin-Watson (Uji DW). Nilai Durbin Watson disajikan pada tabel sebagai berikut:

\begin{tabular}{|l|c|r|r|r|r|}
\hline & $\mathrm{R}$ & R Square & $\begin{array}{c}\text { Adjusted R } \\
\text { Square }\end{array}$ & $\begin{array}{c}\text { Std. Error of the } \\
\text { Estimate }\end{array}$ & $\begin{array}{c}\text { Durbin- } \\
\text { Watson }\end{array}$ \\
\hline 1 & $.673^{\mathrm{a}}$ & .453 & .434 & 1.65760 & 2.035 \\
\hline
\end{tabular}

a. Predictors: (Constant), Etika Profesi, Independensi, Profesionalisme

b. Dependent Variable: Kinerja Auditor

Sumber data : Output SPSS (data diolah)

Dari hasil output di atas didapat nilai Durbin Watson yang dihasilkan dari model regresi adalah 2,035. Karena nilai Durbin Watson 2,035 terletak di antara dU $(1,7232)$ dan 4- 
dU (2,2768). Karena 1,7232 <2,035 < 2,2768 sehingga disimpulkan bahwa tidak terjadi autokorelasi.

\section{Uji Multikolinearitas}

Untuk mendeteksi ada atau tidaknya multikolinearitas dalam suatu persamaan regresi adalah sebagai berikut: nilai Tolerance yang rendah maka akan berakibat pada VIF yang tinggi, dan ini berarti terjadi multikolinearitas. Untuk mengetahui ada tidaknya multikolinearitas dapat dilihat pada tabel coefficients berikut ini:

\begin{tabular}{|c|c|c|c|}
\hline \multirow{2}{*}{\multicolumn{2}{|c|}{ Model }} & \multicolumn{2}{|c|}{ Collinearity Statistics } \\
\hline & & Tolerance & VIF \\
\hline \multirow{3}{*}{1} & Profesionalisme & .702 & 1.425 \\
\hline & Independensi & .760 & 1.316 \\
\hline & Etika profesi & .832 & 1.202 \\
\hline
\end{tabular}

a. dependent variable: kinerja auditor

Sumber data: Output SPSS 21 (data diolah)

Berdasarkan tabel di atas, diketahui bahwa nilai variance inflation factor (VIF) menunjukkan besarnya nilai Tolerance dan Variance Inflation factor (VIF) untuk masingmasing variabel independen yaitu tolerance $>0,10$ dan nilai VIF $<10$ sehingga dapat disimpulkan bahwa antar variabel independen tidak terjadi multikolinearitas.

\section{Uji Heteroskedastisitas}

Model regresi yang baik adalah tidak terjadi heteroskedastisitas. Dasar analisis adalah sebagai berikut: (1) jika ada pola tertentu, seperti titik-titik yang ada membentuk suatu pola tertentu yang teratur, maka telah terjadi heteroskedastisitas. (2) jika tidak ada pola yang jelas, serta titik-titik menyebar di atas dan di bawah angka 0 pada sumbu Y, maka tidak terjadi heteroskedastisitas. Untuk mengetahui apakah terdapat heteroskedastisitas atau tidak pada model regresi dapat dilihat pada gambar di bawah ini.

Dari grafik scatterplot di bawah ini bahwa model penelitian tidak mengalami gangguan heteroskedastisitas, karena grafik scatterplot tidak membentuk pola yang jelas pada grafik tersebut. Titik-titik pada grafik nampak terlihat menyebar di atas dan di bawah angka 0 pada sumbu Y.

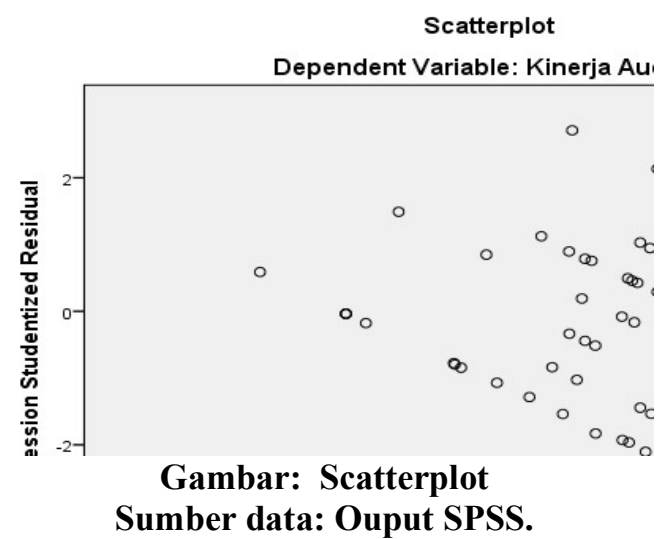




\section{Analisis Regresi Linier Berganda}

berikut:

Dengan menggunakan SPSS for windows diperoleh hasil koefisien regresi sebagai

Tabel. Coefficients ${ }^{a}$

\begin{tabular}{|c|c|c|c|c|c|c|}
\hline \multirow{2}{*}{\multicolumn{2}{|c|}{ Model }} & \multicolumn{2}{|c|}{$\begin{array}{l}\text { Unstandardized } \\
\text { Coefficients }\end{array}$} & \multirow{2}{*}{$\begin{array}{c}\begin{array}{c}\text { Standardized } \\
\text { Coefficients }\end{array} \\
\text { Beta }\end{array}$} & \multirow[b]{2}{*}{$\mathrm{T}$} & \multirow[b]{2}{*}{ Sig. } \\
\hline & & $\mathrm{B}$ & Std. Error & & & \\
\hline & (Constant) & .812 & 3.786 & & .214 & .831 \\
\hline & Profesionalisme & .198 & .088 & .219 & 2.259 & .027 \\
\hline & Independensi & .361 & .082 & .411 & 4.419 & .000 \\
\hline & Etika Profesi & .222 & .085 & .234 & 2.627 & .010 \\
\hline
\end{tabular}

a. Dependent Variable: Kinerja Auditor

Sumber data : Output SPSS (data diolah)

Berdasarkan tabel di atas, maka dapat dibuat persamaan regresi linier berganda sebagai berikut :

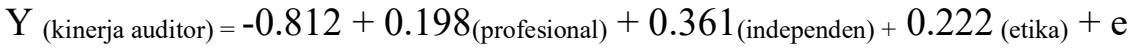

Dari persamaan regresi di atas dapat di interprestasikan beberapa hal antara lain :

1. Nilai Constant sebesar -0.812 menunjukkan pengaruh positif variabel independen (profesionalisme auditor, independensi auditor dan etika profesi). Jika variabel independen naik atau berpengaruh dalam satu satuan, maka variabel kinerja auditor akan naik atau terpenuhi sebesar 0,812 .

2. Nilai koefisien regresi variabel profesionalisme auditor (X1) bernilai positif, yaitu sebesar 0,198 ini dapat diartikan bahwa setiap peningkatan profesionalisme auditor sebesar 1 , maka kinerja auditor juga meningkat sebesar 0,198 atau $19,8 \%$.

3. Nilai koefisien regresi variabel independensi auditor (X2) bernilai positif, yaitu sebesar 0,361 ini dapat diartikan bahwa setiap peningkatan independensi auditor sebesar 1 , maka kinerja auditor juga meningkat sebesar 0,361 atau $36,1 \%$.

4. Nilai koefisiensi regresi variabel etika profesi (X3) bernilai positif, yaitu sebesar 0,222 ini dapat diartikan bahwa setiap peningkatan etika profesi sebesar 1, maka kinerja auditor juga meningkat 0,222 atau $22,2 \%$.

\section{Uji Hipotesis}

\section{Koefisien Determinasi}

Koefisien determinasi $\left(\mathrm{R}^{2}\right)$ digunakan untuk mengukur seberapa jauh kemampuan model dapat menjelaskan variasi variabel dependen. Nilai $\mathrm{R}^{2}$ yang kecil berarti kecil juga kemampuan variabel-variabel independen dalam menjelaskan variasi variabel dependen yang sangat terbatas. Koefisien determinasi adalah kuadrat dari nilai korelasi pada tabel Model Summary Output SPSS yang dapat dihasilkan sebagai berikut:

Tabel Model Summary

\begin{tabular}{|c|c|c|c|c|}
\hline Model & $\mathrm{R}$ & $\mathrm{R}$ Square & $\begin{array}{c}\text { Adjusted } \mathrm{R} \\
\text { Square }\end{array}$ & $\begin{array}{c}\text { Std. Error of the } \\
\text { Estimate }\end{array}$ \\
\hline 1 & $.673^{\mathrm{a}}$ & .453 & .434 & 1.65760 \\
\hline
\end{tabular}

a. Predictors: (Constant), Etika Profesi, Independensi, profesionalisme b. Dependent Variable: kinerja auditor 
Berdasarkan tabel di atas diperoleh bahwa nilai koefisien determinasi (adjusted $\mathrm{R}^{2}$ ) sebesar 0.434 atau sebesar 43,4\%. Hal ini berarti bahwa variabel independesi auditor, profesionalisme auditor, dan etika profesi mampu menjelaskan variabel kinerja auditor sebesar $43,4 \%$, sedangkan sisanya $56.6 \%$ dipengaruhi oleh faktor-faktor lain yang tidak dimasukkan dalam model regresi dalam penelitian ini.

\section{Uji statistik t (Uji Signifikan Parsial)}

Uji t yaitu suatu uji untuk mengetahui signifikansi pengaruh variabel independen (profesionalisme auditor, independensi auditor, dan etika profesi terhadap kinerja auditor) secara parsial atau individual menerangkan terhadap variabel dependen (kinerja auditor). Pengujian ini dinilai dengan tingkat signifikansi 0.05 atau $\alpha=5 \%$. Berikut ini adalah kriteria pengujian yang dilakukan:

1. Jika Nilai Sig $<0.05$, maka Ho ditolak dan Ha diterima.

2. Jika Nilai Sig $>0.05$, maka Ho diterima dan Ha ditolak.

Coefficients $^{\mathrm{a}}$

\begin{tabular}{|c|c|c|c|c|c|c|}
\hline \multirow{2}{*}{\multicolumn{2}{|c|}{ Model }} & \multicolumn{2}{|c|}{$\begin{array}{c}\text { Unstandardized } \\
\text { Coefficients }\end{array}$} & \multirow{2}{*}{$\begin{array}{c}\text { Standardized } \\
\text { Coefficients } \\
\text { Beta }\end{array}$} & \multirow[b]{2}{*}{1} & \multirow[b]{2}{*}{ Sig. } \\
\hline & & $\mathrm{B}$ & Std. Error & & & \\
\hline \multirow[t]{4}{*}{$\overline{7}$} & (Constant) & .812 & 3.786 & & .214 & .831 \\
\hline & Profesionalisme & .198 & .088 & .219 & 2.259 & .027 \\
\hline & Independensi & .361 & .082 & .411 & 4.419 & .000 \\
\hline & Etika Profesi & .222 & .085 & .234 & 2.627 & .010 \\
\hline
\end{tabular}

a. Dependent Variable: Kinerja Auditor

Berdasarkan tabel di atas, maka dapat dijelaskan mengenai pengaruh secara parsial masing-masing variabel independen sebagai berikut :

\section{Pengaruh profesionalisme auditor terhadap kinerja auditor}

Tabel di atas menunjukkan bahwa profesionalisme auditor memiliki tingkat sig 0.027 , dimana nilai tersebut lebih kecil dari 0.05. Sehingga dapat disimpulkan bahwa Ho ditolak dan Ha diterima, yang berarti terdapat pengaruh positif profesionalisme auditor terhadap kinerja auditor sebesar 19,8 persen.

Untuk menjalankan tanggung jawab audit dengan baik maka akuntan publik memerlukan sikap profesionalisme yang selalu ditanamkan dalam diri mereka. Apabila seorang auditor tidak memiliki atau telah kehilangan sikap profesionalismenya sebagai seorang auditor maka sudah dapat diyakini bahwa auditor tersebut tidak akan dapat menghasilkan hasil kinerja yang memuaskan dan dengan baik, maka dengan begitu kepercayaan dari masyarakat akan hilang begitu saja terhadap auditor tersebut.

Hasil penelitian ini sesuai dengan hasil penelitian oleh Ernawati Putri Sholikhah tahun 2017 yang menyimpulkan bahwa profesionalisme auditor berpengaruh terhadap kinerja auditor.

\section{Pengaruh independensi auditor Terhadap kinerja auditor}

Tabel di atas menunjukkan bahwa indenpendensi auditor memiliki tingkat sig 0.000 , dimana nilai tersebut lebih kecil dari 0.05. Sehingga dapat disimpulkan bahwa Ho 
ditolak dan Ha diterima, yang berarti terdapat pengaruh independensi auditor terhadap kinerja auditor sebesar 36,1 persen.

Seorang auditor yang memiliki sikap independen tinggi dalam melakukan audit, maka hasil pemeriksaannya akan sesuai dengan fakta-fakta yang ada sehingga kinerja auditor diharapkan semakin baik. Auditor yang menegakkan independensinya, tidak akan terpengaruh dan tidak dipengaruhi oleh berbagai kekuatan yang berasal dari luar diri auditor dalam mempertimbangkan fakta yang dijumpainya dalam pemeriksaan.

Hasil penelitian ini sesuai dengan hasil penelitian Listya Nuraini tahun 2016 yang menyimpulkan bahwa independensi auditor berpengaruh terhadap Kinerja Auditor.

\section{Pengaruh etika profesi terhadap kinerja auditor}

Tabel di atas menunjukkan bahwa etika profesi memiliki tingkat sig 0.010, dimana nilai tersebut lebih kecil dari 0.05 . Sehingga dapat disimpulkan bahwa Ho ditolak dan Ha diterima, yang berarti terdapat pengaruh etika profesi terhadap kinerja auditor sebesar 22,2 persen.

Etika profesi merupakan karakteristik suatu profesi yang membedakan suatu profesi dengan profesi lain, yang berfungsi untuk mengatur tingkah laku para anggotanya. Hubungan antara etika profesi dengan kinerja auditor dimana etika profesi termasuk didalamnya kode etik atau etika auditor akan mengarahkan pada sikap, tingkah laku, dan perbuatan auditor dalam menjalankan tugas dan kewajibannya kaitannya untuk menjaga mutu auditor yang tinggi.

Hasil penelitian ini konsisten dengan penelitian yang dilakukan oleh Anis Choiriah tahun 2013, yang menunjukkan bahwa etika profesi berpengaruh signifikan positif terhadap kinerja auditor.

\section{Uji statistik F (Uji Signifikan Simultan)}

Uji statistik F menunjukkan apakah semua variabel independen yang dimasukkan dalam model mempunyai pengaruh secara bersama-sama terhadap variabel terikat. Pengujian dilakukan dengan tingkat signifikansi 0.05 atau $\alpha=5 \%$. Uji F dilihat dalam tabel ANOVA output SPSS dalam kolom sig, jika probabilitas $<0.05$ maka dapat dikatakan terdapat pengaruh secara bersama-sama variabel independen terhadap variabel dependen dan model regresi bisa dipakai untuk memprediksi variabel dependen. Atau jika nilai signifikan $>0.05$ maka tidak terdapat pengaruh secara bersama-sama antar variabel independen terhadap variabel dependen. Berikut ini adalah kriteria pengujian yang dilakukan:

a. Jika Sig $<0.05$, maka Ho ditolak dan Ha diterima.

b. Jika Sig $>0.05$, maka Ho diterima dan Ha ditolak.

Tabel. ANOVA ${ }^{a}$

\begin{tabular}{|ll|r|r|r|r|r|}
\hline Model & & Sum of Squares & Df & Mean Square & F & \multicolumn{1}{c|}{ Sig. } \\
\hline 1 & Regression & 189.209 & 3 & 63.070 & 22.954 & $.000^{\mathrm{b}}$ \\
& Residual & 228.055 & 83 & 2.748 & & \\
& Total & 417.264 & 86 & & & \\
\hline
\end{tabular}

a. Dependent Variable: Kinerja Auditor

b. Predictors: (Constant), Etika Profesi, Independensi, Profesionalisme

Sumber Data: Output SPSS

Berdasarkan tabel di atas dapat diketahui hasil uji ANOVA atau uji F. Nilai probabilitas $0.000^{\mathrm{b}}<0.05$. Maka variabel etika professional, independensi auditor, dan 
profesionalisme auditor secara simultan berpengaruh terhadap kinerja auditor. Dengan demikian Ho ditolak dan Ha diterima.

\section{KESIMPULAN DAN SARAN}

\section{Kesimpulan}

Adapun kesimpulan yang dapat ditarik oleh peneliti adalah sebagai berikut:

1. Terdapat pengaruh Profesionalisme Auditor terhadap Kinerja Auditor di Kantor Akuntan Publik (KAP) di wilayah Jakarta Barat.

2. Terdapat pengaruh Independensi Auditor terhadap Kinerja Auditor di Kantor Akuntan Publik (KAP) di wilayah Jakarta Barat.

3. Terdapat pengaruh Etika Profesi terhadap Kinerja Auditor di Kantor Akuntan Publik (KAP) di wilayah Jakarta Barat.

4. Secara simultan profesionalisme auditor, independensi auditor dan etika profesi berpengaruh terhadap kinerja auditor di Kantor Akuntan Publik (KAP) di wilayah Jakarta Barat.

\section{Saran} sebagai berikut:

1. Memperluas objek penelitian, misalnya Kantor Akuntan Publik atau Jasa Akuntansi yang terdaftar di IAPI maupun OJK yang bukan hanya berada di wilayah Jakarta Barat.

2. Meneliti faktor-faktor lain yang dapat mempengaruhi Kinerja Auditor selain Profesionalisme Auditor, Independensi Auditor dan Etika Profesi seperti Locus of Control, Komitmen Organisasi, Konflik Peran, Gaya Kepemimpinan, Budaya Organisasi, Struktur Audit, dll.

3. Sebaiknya penyebaran kuesioner tidak dilakukan pada waktu yang bertepatan dengan kesibukan para auditor, sehingga kuesioner yang disebarkan mendapat tanggapan yang baik.

\section{DAFTAR PUSTAKA}

A.A.Anwar Prabu Mangkunegara, 2011, Manajemen Sumber Daya Manusia Perusahaan. Bandung: PT. Remaja Rosda Karya.

Arens A.A, Elder R, J, dan Beasley M, S. 2014. Auditing \& Jasa Assurance Pendekatan Terintegrasi Edisi Kelimabelas Jilid Satu. Jakarta : Salemba Empat.

Ghozali, Imam. 2016. Aplikasi Analisis Multivariete IBM SPSS 23 edisi 8. Penerbit: Universitas Diponegoro. Semarang.

Ghozali, Imam. 2005. Aplikasi Analisis Multivariete IBM SPSS 23 edisi 8. Penerbit: Universitas Diponegoro. Semarang.

Ikatan Akuntan Indonesia, 2011. "Standar Profesional Akuntan Publik". IAI. Jakarta : Salemba Empat.

Mulyadi. 2013. Auditing. Edisi 6. Jakarta : Salemba Empat. 
Sugiyono. 2016. "Metode penelitian kuantitatif kualitatif dan R\&D”. Bandung : Salemba Empat.

Sukrisno Agoes. 2012. Auditing (Petunjuk Praktis Pemeriksaan Akuntan oleh Akuntan Publik). Edisi Keempat. Salemba Empat: Jakarta

Wibowo. (2010). Manajemen kinerja. Edisi Keempat. Jakarta: PT. Raja Grafindo Persada.

Alfianto, Sandy dan Suryandari, Dhini. Pengaruh Profesionalisme, Komitmen Organisasi dan Struktur Audit Terhadap Kinerja Auditor, Accounting Analysis Journal 4 (1) (2015).

Arumsari, Adelia Lukyta dan Budiartha, I Ketut. Pengaruh Profesionalisme Auditor, Independensi Auditor, Etika Profesi, Budaya Organisasi, dan Gaya Kepemimpinan terhadap Kinerja Auditor pada Kantor Akuntan Publik di Bali. E-Jurnal Ekonomi dan Bisnis Universitas Udayana 5.8 (2016): 2297-2304.

Choiriah, Anis. Pengaruh Kecerdasan Emosional, Kecerdasan Intelektual, Kecerdasan Spiritual dan Etika Profesi Terhadap Kinerja Auditor dalam Kantor Akuntan Publik (Studi Empiris Pada Auditor dalam Kantor Akuntan Publik di Kota Padang dan Pekanbaru), Skripsi Fakultas Ekonomi Universitas Negeri Padang.

Nuraini, Listiya. Pengaruh Independensi, Gaya Kepemimpinan dan Budaya Organisasi Terhadap Kinerja Auditor (Studi Empiris Pada Kantor Akuntan Publik Yogyakarta dan Solo). Skripsi Fakultas Ekonomi Universitas Negeri Yogyakarta.

Sholikhah, Ernawati Putri. Pengaruh Independensi, Etika Profesi, Profesionalisme dan Komitmen Organisasi Terhadap Kinerja Auditor (Studi Empiris pada KAP di Kota Surakarta dan Yogyakarta). Skripsi Fakultas Ekonomi Dan Bisnis Islam Institut Agama Islam Negeri Surakarta.

Sitorus, Riris Rotua dan Wijaya, Lenny. Pengaruh Profesionalisme dan Etika Profesi Terhadap Kinerja Auditor dengan Struktur Audit Sebagai Pemoderasi, Media Studi Ekonomi Volume 19 No. 2 ,Juli - Desember 2016.

Yulistiyani, Nenni. Pengaruh Independensi Auditor, Gaya Kepemimpinan, Komitmen Organisasi dan Budaya Organisasi Terhadap Kinerja Auditor (Studi Empiris Pada Kantor Akuntan Publik di Surakarta dan Yogyakarta). Skripsi Fakultas Ekonomi dan Bisnis Universitas Muhammadiyah Surakarta.

www.iapi.or.id 